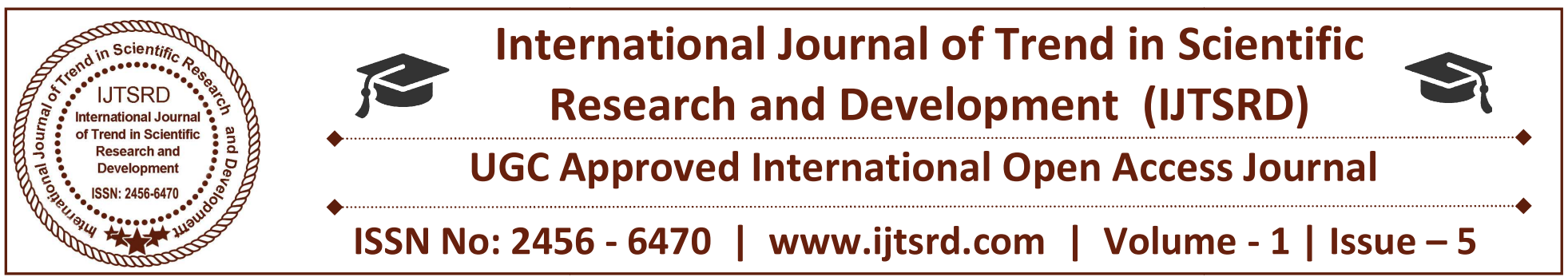

\title{
Assessment of Sulphur Dioxide Levels in Selected Sites in Athi River, Kenya
}

Birgen J.

University of Nairobi, School of Physical Sciences, Department of Chemistry, Nairobi, Kenya

Yusuf A.

University of Nairobi, School of Physical Sciences, Department of Chemistry, Nairobi, Kenya

\author{
Wafula G. \\ University of Nairobi, School of Physical Sciences, \\ Department of Chemistry, Nairobi, Kenya \\ Onyatta J. \\ University of Nairobi, School of Physical Sciences, \\ Department of Chemistry, Nairobi, Kenya
}

\begin{abstract}
Industrialization, economic growth, urbanization and population growth have been responsible for air pollution in developing countries. The discharge of harmful chemicals and increased combustion of fossil fuels, affect both the physical environment and the public health. Air pollution effects are both acute and chronic on human health, ranging from minor upper respiratory irritation to chronic respiratory and heart disease, lung cancer, acute respiratory infections in children and chronic bronchitis in adults. A study was conducted to assess the effect of sulfur dioxide on air quality at three sites in Athi River town, Kenya which included one non-industrial site. The air samples were collected by scrubbing them through appropriate

concentrations of sulphur dioxide during the dry season for Shalom Hospital, Vanillaz Restaurant, Redeemed Gospel church and Sabaki residential Estate were 863, 875,862 and $664 \mu \mathrm{g} / \mathrm{m} 3$ respectively. The elevated levels of SO2 was associated with heavy vehicular traffic and the various industrial activities mainly cement manufacturing plants. Sulphur dioxide may also be emitted from diesel-powered vehicles and coal burning in the industries. The study revealed that Shalom Hospital, Vanillaz Restaurant and Redeemed Gospel Church were polluted with sulphur dioxide during the rainy season except Sabaki residential Estate but during the dry season all the sites were polluted with sulphur dioxide.
\end{abstract} trapping solutions and subsequently analyzed in the laboratory using colorimetric method. The meteorological parameters namely; temperature, relative humidity, wind speed and wind direction were also measured during the sampling exercise. The mean concentrations of sulphur dioxide at the various sampling sites during rainy season were: Shalom Hospital $(602 \mu \mathrm{g} / \mathrm{m} 3)$;

Vannilaz Restaurant (793 $\mu \mathrm{g} / \mathrm{m} 3$ ); Redeemed Gospel Church $(861 \mu \mathrm{g} / \mathrm{m} 3)$ and Sabaki residential Estate (370 $\mu \mathrm{g} / \mathrm{m} 3)$. The levels exceeded the guidelines recommended by WHO which has set a maximum of $500 \mu \mathrm{g} / \mathrm{m} 3$, for 10 minutes exposure, however the levels at Sabaki residential Estate were low. Mean
Keywords: Air pollution, parameters, Industrial sites, WHO standards

\section{INTRODUCTION}

Air pollution is defined as the presence of any solid, liquid or gaseous substance including noise and radioactive radiation in the atmosphere in such concentration that could harm the health of humans and animals, or could damage plants and materials. (Alias et al, 2007). Sources of air pollution are categorized as either anthropogenic (caused by human activities like coal combustion, industries and exhaust fumes) or biogenic (caused by dust storms and 
volcanic eruptions). Air pollution causes harmful change in the physical, chemical or biological features of air and may destructively affect the life of any living organism. Some of the major sources of air pollution are automobiles and industries. Air pollution from vehicles pollution is $60 \%$, followed by industries at $20-30 \%$ in urban centers. In Kenya, car imports increased by $50 \%$ between the year 1992-1999 (Maina, 2004). Cement manufacture is among the industries that significantly pollute the air due to the discharge of toxic fumes, gases, smoke and dusts into the atmosphere (Park and Park, 1985). Cement is produced from raw materials such as limestone, chalk, clay and sand.

The rapid increase in urbanization and industrialization has caused a strain on the town's services. This has resulted in increased demand for transportation, industrial production and energy requirements, giving rise to air pollution. Increased population in urban centers intensifies air pollution due to inadequate green open spaces in towns and cities (Givoni, 1991). Cement industries in Athi River, Kenya are thriving due to the rapid population growth and the availability of raw materials. Cement demand in Kenya is expected to increase because of the Government's plans to build new housing units and also to meet vision 2030 (GoK, 2007). Unless restricted regulations are enforced by government to ensure compliance with national and international standards upon this industry, the increase of cement plants and their associated pollutions may lead to deterioration of air quality.

Air pollution in industrial areas is on the rise due to industrial growth, high traffic density and urbanization. It is a major problem because it has adverse effects on human health, materials and the environment. Occupational asthma, silicosis and asbestosis have been reported among industrial workers in battery manufacturing, cement production and mineral processing plants in Nairobi, Athi River, Thika and Mombasa (Kahenya, 1996). Air pollution also contributes to formation of acid rain, which has been responsible for the reduction in soil fertility, destruction of aquatic ecosystems including fisheries resources and death of certain crops. Acid rain further accelerates corrosion of metallic and other building structures which sometimes may be located far away from the pollutant source (Rao et al, 2003). In 2002, Mogere (2002), showed increased air pollution in Athi River. This was attributed to industrialization and heavy traffic flow, hence, there is a great need for continuous monitoring of air quality to determine the levels of these air pollutants being emitted into the environment and establish the extent of human exposure to such risk.

The health effects of sulphur dioxide (SO2) are nose and throat irritations (Balmes et al., 1987). Exposure to high levels of sulphur dioxide causes respiratory problems, changes in the lung's defenses, and worsening cardiovascular diseases (Nemery et al., 2001). Sulphur dioxide (SO2) in moderate concentrations may result in a fall in lung function for asthmatics. SO2 is a major contributor of acidic precipitation since it forms sulphuric acid. Sulphur dioxide is harmful to plant leaves as it darkens it and also makes the leaves flaccid and finally drop. This is due to the formation of sulphite (SO3 2-) and sulphate ions (SO4 2- ) in the leaf when sulphur dioxide enters through the stomata and reacts with water. The leaf tissue finally dies (Strauss and Mainwaring, 1984). The oxidation of sulphur dioxide to sulphur trioxide (SO3) in the atmosphere leads to formation of fog, due to poor dispersal of pollutants (Lenchev et al., 2008).

The objective of this study was to determine the levels of sulphur dioxide in air and the effect of metrological parameters on the levels. The levels of sulphur dioxide were then compared with WHO air quality standards.

\section{MATERIALS AND METHODS}

\subsection{Description of the Study Sites}

Athi River is located at latitude $1.45^{\circ}$ South (1027'27.8'S), longitude 36.98 East (36058'42.6”E) and 1532 meters elevation above the sea level. Athi River Town is in Kenya, in Machakos County, Mavoko constituency. The town hosts Mavoko Municipal Council and headquarters of Mavoko division. The town's air is polluted due to many manufacturing industries and tanneries situated here. The area is under semi-arid ecosystem with the main industries being cement manufacturing plants. It is relatively industrialized with six cement factories, which include: Bamburi Cement Company, Mombasa Cement Limited, Athi River Mining, East Africa Portland Cement, National Cement Company and Savannah Cement Company. The map of the study area, Athi River is given in Figure 2.1. Athi River is approximately $693 \mathrm{~km} 2$ with a population of 139,380 according to the 2009 census. Its population growth 
using statistics from Kenya National Bureau of Statistics (KNBS) is around $2.5 \%$. Its approximate population was estimated to be 156,802 in 2016 . The study was conducted to determine the air borne levels of sulphur dioxide in Athi River Town and compare with WHO allowable limit.

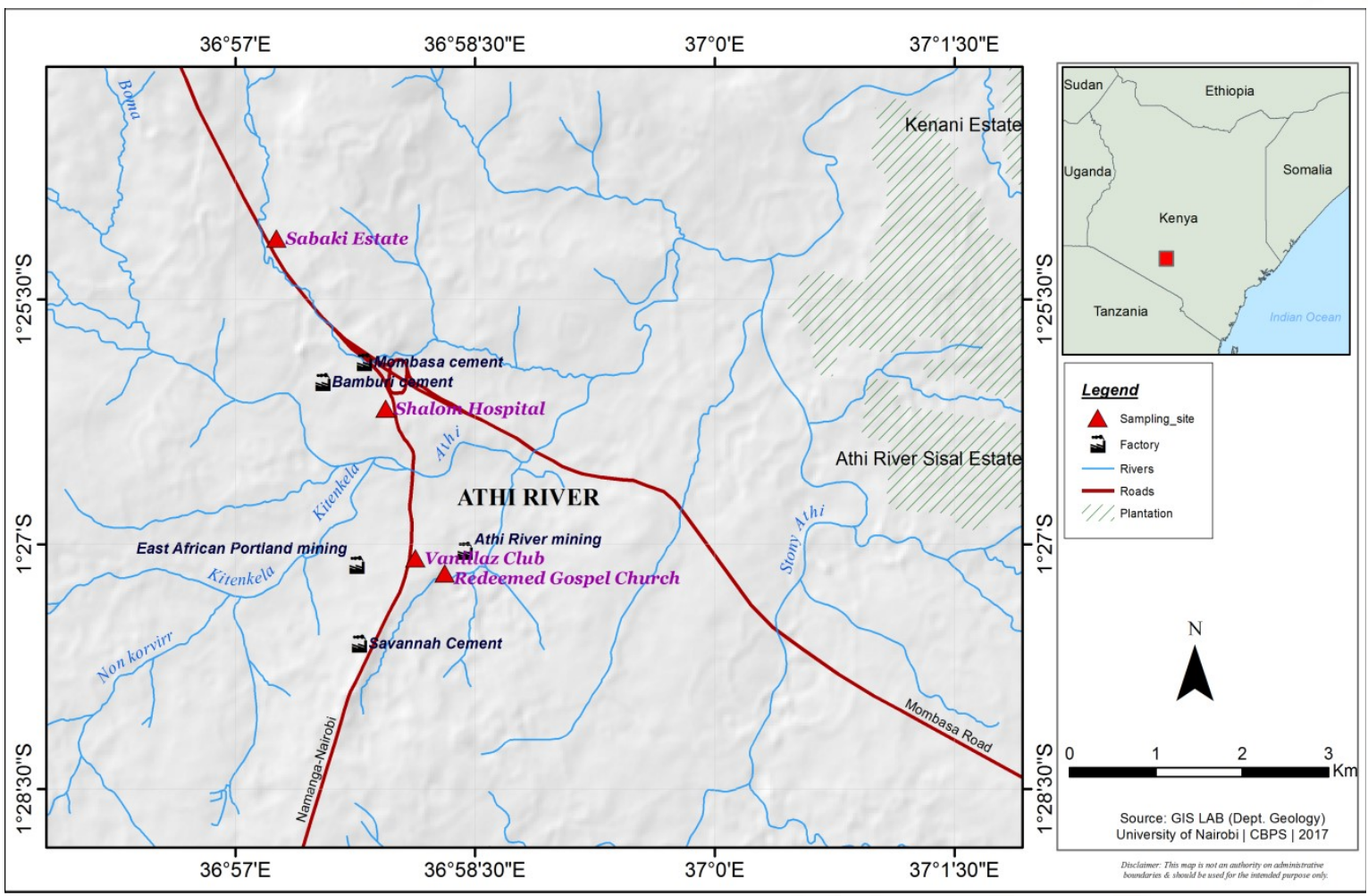

Figure 2.1.: Athi River, Study site (Source: GIS LAB, 2017)

The monitoring stations chosen for this study were free from any interference from the surrounding that would prevent free air flow from the ambient atmosphere. Sampling was done at $1.5 \mathrm{~m}$ height. Four sites were selected. Site A (Shalom Hospital), Site B (Vanillaz club), Site C (Redeemed Gospel Church) and Site D (Sabaki residential Estate) as shown in Figure 2.1

\subsubsection{Shalom Hospital}

The study site was near Shalom Hospital (see Figure 2.1) and situated in an industrial environment with an open terrain. The industries found within the vicinity include: Mombasa Cement Company (400 meters from the study site) and Bamburi cement plant (600 meters from the study site). The study area has busy terrific that carry raw materials as well as finished cement products into and out of cement plants. There are also fleets of motor vehicles along the MombasaNamanga road which connects Kenya with Tanzania.
All these anthropogenic activities could contribute the pollution of the study area.

\subsubsection{Site B: Vannilaz club}

Site B (Vannilaz club) is located at the junction of Makadara road along Nairobi-Namanga highway (Figure 2.1). The East Africa Portland Cement Company (EAPCC) is located south west of the site while Athi River Mining Cement Company (ARM) is located to north east of the site. The site is close to a furniture mart, business premises, a club, restaurant, shops and car wash yard. Biomass is used for heating and cooking in the site.

\subsubsection{Site C: Redeemed Gospel Church}

The Redeemed Gospel Church has primary school within the church compound. It is along the Makadara-Athi River road as shown in Figure 2.1. The site is surrounded by Associated Battery Manufacturers and recycling company (ABM), Athi 
River Mining Cement Company (ARM) and a quarry. The factories, ABM and ARM are about 200 meters away from the site while the quarry is adjacent to the church fence about 50 meters from the sampling site.

\subsubsection{Site D: Sabaki Residential Estate.}

The site is a residential Estate about $2 \mathrm{~km}$ from Mombasa road (Figure 2.1). It is a non-industrial area with less vehicular traffic and housing construction is the major activity in this place.

\subsection{Air Sampling Apparatus}

The sampling apparatus consisted of the following: a 220/240 volts electric power driven suction pump (Charles Austen Pumps Limited, England), fitted with a 10 meter rubber tubing and 70 meter power cable, a portable Tiger generator, an impinger or glass trapper, a wet and dry hygrometer with conversion tables (Russell Scientific Instruments Limited, England), together with a thermometer for temperature monitoring, a filter holding tube with filter papers (Whatman membrane filters $0.2 \mu \mathrm{m}$ pore size) and anemometer for monitoring wind speed.

\subsection{Sampling Procedures}

Air samples were scrubbed through appropriate trapping solution using a portable suction pump (Figure 2.2) of known flow rate according to active sampling method. The impinger was rinsed with distilled water, followed by the appropriate trapping of sulphur dioxide using $0.1 \mathrm{M}$ sodium tetrachloromercurate (TCM) solution. The trapping solution $(50 \mathrm{ml})$ was transferred into an impinger using a graduated pipette. The impinger inlet was connected to $10 \mathrm{~m}$ rubber tubing, whereas the impinger outlet was connected with $30 \mathrm{~cm}$ rubber tubing with the suction pump. The 10 meter rubber tubing was then tied to a convenient hook where sampling was done. For the suspended particulate matter, the impinger was replaced with filter holding tube fitted with filter paper. Sampling at all the sites was done for 15 minutes. Air Sampling was done at the specific sites during the day (morning and afternoon) and it covered both the dry and rainy seasons. The meteorological parameters namely wind speed, wind direction; relative humidity and temperatures were measured during sampling exercise. All samples were stored in $120 \mathrm{ml}$ plastic bottles, tightly sealed and transferred to laboratory for analysis of the sulfur dioxide content. Filter papers were also stored in sealed plastic bags.

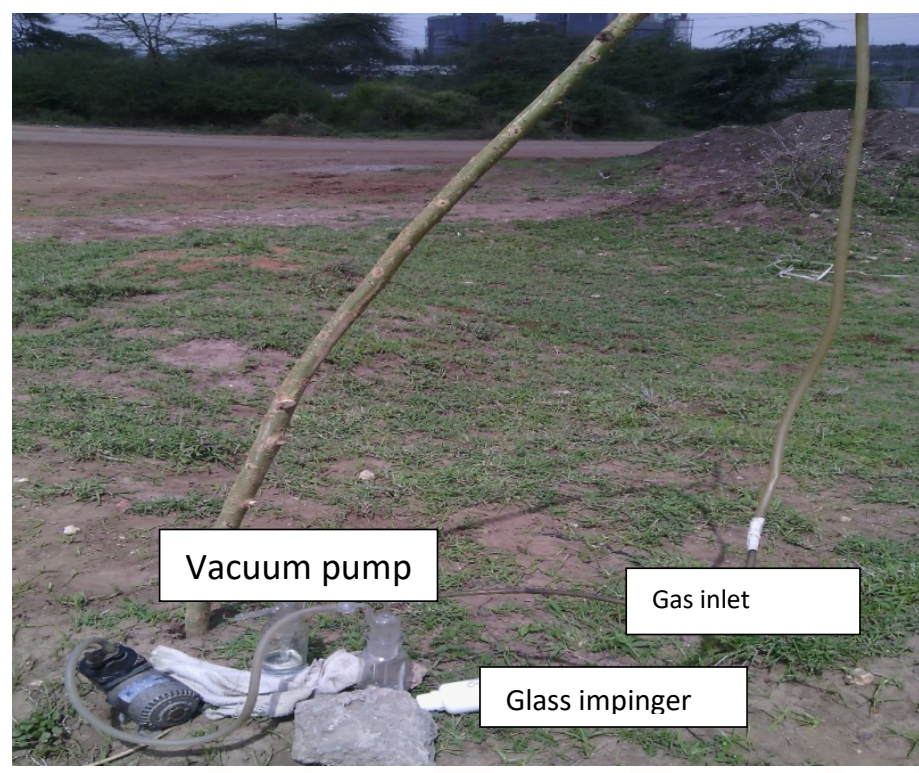

Figure 2.2: Air sampling train

\subsubsection{Experimental procedure for analysis of samples}

$10 \mathrm{ml}$ sample was taken from the original $50 \mathrm{ml}$ of the trapping solution and placed in a $50 \mathrm{ml}$ volumetric flask (dilution factor of 5) and $2 \mathrm{ml}$ of $0.6 \%$ sulphamic acid was added. The solution was allowed to react for 10 minutes to destroy nitrite. $4 \mathrm{ml}$ of $0.2 \%$ formaldehyde was added followed by $4 \mathrm{ml}$ of $0.04 \%$ pararosaniline solution and the solution was made to the mark with $0.1 \mathrm{M}$ tetrachloromercurate trapping solution. The blank solution (reference) containing only $0.1 \mathrm{M}$ TCM and the standards were treated in the same way as samples. Distilled water optical reference. Samples were analyzed using UV-Visible spectrophotometer and the absorbance was then measured at 560nm spectrophotometrically using Shimadzu Uv-1700 pharmaspec spectrophotometer.

A calibration graph of absorbance against concentration gave a slope of 0.326 with an intercept of 0.0398 and a Pearson's correlation of $99.55 \%$. The relationship between absorbance and concentration is described by equation 2.1 .

$\mathrm{A}=\mathrm{ax}+\mathrm{b}$

Where $\mathrm{A}$ is absorbance, $\mathrm{a}$ is the slope, $\mathrm{x}$ is the concentration and $\mathrm{b}$ the intercept.

\section{RESULTS}

The average levels of the pollutants during wet season and dry seasons are given in Table 1 . 
Table 1: The average levels of sulphur dioxide in the four study sites during the wet and dry seasons

\begin{tabular}{|c|c|c|}
\hline \multirow{2}{*}{ Site } & \multicolumn{2}{|c|}{ Concentration of $\mathrm{SO}_{2}\left(\mathrm{\mu g} / \mathrm{m}^{3}\right)$ (Exposure time 10 minutes) } \\
\cline { 2 - 3 } & Wet season & Dry season \\
\hline Shalom Hospital (A) & $602 \pm 84$ & $863 \pm 33$ \\
\hline Vannilaz Club (B) & $793 \pm 62$ & $875 \pm 27$ \\
\hline Redeemed Gospel Church (C) & $861 \pm 26.4$ & $862 \pm 44$ \\
\hline Sabaki River Estate (D) & $370 \pm 57$ & $664 \pm 23$ \\
\hline WHO value & 500 & 500 \\
\hline
\end{tabular}

The factors (humidity, wind direction and speed and temperature) that could influence the levels $\mathrm{SO}_{2}$ during the dry and wet seasons at the study sites are provided in Table 2.

Table 2 Mean Relative humidity, wind direction, wind speed and temperature during wet and dry seasons

\begin{tabular}{|c|c|c|c|c|c|c|c|c|c|}
\hline \multirow[t]{2}{*}{$\begin{array}{l}\text { Sampling } \\
\text { site }\end{array}$} & \multirow[t]{2}{*}{$\begin{array}{l}\text { Period } \\
\text { of day }\end{array}$} & \multicolumn{2}{|c|}{$\begin{array}{l}\text { Relative } \\
\text { Humidity }\end{array}$} & \multirow{2}{*}{\multicolumn{2}{|c|}{$\begin{array}{l}\text { Wind } \\
\text { speed } \\
\text { (m/sec) } \\
\text { Season }\end{array}$}} & \multicolumn{2}{|c|}{ Wind direction } & \multicolumn{2}{|c|}{ Temperature ${ }^{0} \mathrm{C}$} \\
\hline & & & $\underline{\text { n }}$ & & & $\overline{\text { Wet }}$ & Dry & $\overline{\text { Wet }}$ & Dry \\
\hline \multirow[t]{2}{*}{ Site A } & AM & $60-51$ & $61-58$ & & $1-1.5$ & $\begin{array}{l}\text { NW } \\
\text { SW }\end{array}$ & $\begin{array}{l}\text { SW } \\
\text { NW }\end{array}$ & $23-26$ & \\
\hline & PM & $55-54$ & $54-53$ & $2-3$ & $1.5-2$ & $\begin{array}{l}\text { NW } \\
\text { SW }\end{array}$ & $\begin{array}{l}\text { SW } \\
\text { NW }\end{array}$ & $26-28$ & $26-27$ \\
\hline \multirow[t]{2}{*}{ Site B } & $\mathrm{AM}$ & $62-56$ & $62-54$ & $2-2.5$ & $1-1.5$ & $\begin{array}{l}\text { NW } \\
\text { SW }\end{array}$ & $\begin{array}{l}\text { NW } \\
\text { NW }\end{array}$ & 25 & $24-27$ \\
\hline & PM & $55-51$ & $64-53$ & $2.5-3$ & $1-2$ & $\begin{array}{l}\text { SW } \\
W\end{array}$ & NW & $27-29$ & $24-27$ \\
\hline \multirow[t]{2}{*}{ Site C } & AM & $62-56$ & $61-58$ & $1.5-2$ & $1.5-2$ & SW & SW & $24-25$ & $24-26$ \\
\hline & $\mathrm{PM}$ & $55-51$ & $58-53$ & $1.5-2$ & $2-2.5$ & SW & SW & $26-27$ & $24-28$ \\
\hline \multirow[t]{2}{*}{ Site D } & AM & $66-56$ & $58-55$ & $1.5-2$ & $1.5-2$ & $\mathrm{~W}, \mathrm{SW}$ & NW & $24-25$ & $24-26$ \\
\hline & PM & $59-52$ & $55-53$ & $1.5-2$ & $1-1.5$ & $\mathrm{NW}, \mathrm{S}$ & NW & $26-28$ & $26-27$ \\
\hline
\end{tabular}

$\mathbf{A M}=$ Morning; $\mathbf{P M}=$ Afternoon 


\section{DISCUSSION}

\section{Pollution levels of sulphur dioxide in air at the four study sites}

\section{Shalom Hospital study site (A)}

The levels of sulphur dioxide during the wet and dry seasons were $602 \mu \mathrm{g} / \mathrm{m} 3$ and $863 \mu \mathrm{g} / \mathrm{m} 3$ respectively. Both values were above the WHO recommended value of $500 \mu \mathrm{g} / \mathrm{m} 3$ at the exposure time of ten (10) minutes. The high concentration of $\mathrm{SO} 2$ at the site could be attributed to the presence of Bamburi Cement and Mombasa Cement factories that are located in the area.

Bamburi Cement is about $500 \mathrm{~m}$ to the west while Mombasa Cement is about $500 \mathrm{~m}$ to the north-west. Clinker raw materials and gypsum contain sulphur which forms $\mathrm{SO} 2$ during combustion and this process could have enhanced the levels of SO2 in the air. The presence of Devki steel plant and tannery could also contribute to the higher levels of SO2. Many of these industries use fuel oil which contains sulphur. Other contributing factors in the area include: high vehicular traffic along Bamburi road and along MombasaNamanga highway.

\section{Vannilas Club study site (B)}

The mean levels of SO2 during the wet and dry seasons were $875 \mu \mathrm{g} / \mathrm{m} 3$ and $793 \mu \mathrm{g} / \mathrm{m} 3$ respectively. The levels exceeded the WHO allowable limits of 500 $\mu \mathrm{g} / \mathrm{m} 3$. The high level of SO2 could be attributed to adjacent Athi River Mining Company and East Africa Portland Cement Company which use fuel oil and pyrites $(\mathrm{FeS})$ in their operations. The emission of $\mathrm{SO} 2$ from fuel combustion by the engines from the traffic along the Namanga-Mombasa Highway could contribute to the high levels of $\mathrm{SO} 2$. The low concentration of $\mathrm{SO} 2$ during the dry season could be due to wind dispersal that dilutes the pollutant.

\section{Redeemed Gospel Church Study Site (C)}

Sulphur dioxide mean levels during the dry season were $862 \mu \mathrm{g} / \mathrm{m} 3$ and $861 \mu \mathrm{g} / \mathrm{m} 3$ during the wet season. The results exceeded WHO standard of 500 $\mu \mathrm{g} / \mathrm{m} 3$ (for 10 minutes determination time). The high level SO2 is attributed to quarrying activities, leadacid battery recycling plant, Kifaru Maize Millers and Athi River Mining Company. These industries use fossil fuels which contributed to the high levels of the pollutant.

\section{Sabaki Residential estate (D)}

The SO2 mean level during the dry season was 664 $\mu \mathrm{g} / \mathrm{m} 3$ slightly above WHO standard of $500 \mu \mathrm{g} / \mathrm{m} 3$. The observed SO2 levels could be due to pollution from nearby industries which are carried along by the wind. These industries include Bamburi Cement and Mombasa cement. The mean level during wet season was $370 \mu \mathrm{g} / \mathrm{m} 3$ (Table 1). The value was below the WHO limit of $500 \mu \mathrm{g} / \mathrm{m} 3$ (for 10 minute exposure). This could be due to reduced vehicular movement since it is a residential area which is about $1 \mathrm{~km}$ from the highway. Since it is a residential site, manufacturing industries were far hence lower levels of $\mathrm{SO} 2$ were observed.

\section{Environmental Factors Influencing Sulphur Dioxide Pollution in the Air}

The results of this study indicate that the following factors should be considered when analyzing $\mathrm{SO} 2$ pollution in the air.

\section{Wind Speed and Direction}

The wind speed ranged from 1-3 m/sec which was moderate for both dry and wet seasons. High concentrations occur when the wind speed is less than $2 \mathrm{~m} / \mathrm{s}$, speed high enough to blow a paper along the ground (Fisher et al., 2005). Strong winds transport pollutants to a large area, while in stable or moderate environment there is little mixing and the air pollutants build up. This may result to high pollutant levels due to stagnant conditions and longer residence time of particulates in the atmosphere. Wind speed affects the dispersal and dilution of pollutants. The higher the wind speed, the higher the dispersal of air pollutants and the lower their concentrations. The Pearson's correlation of wind speed in relation to concentration shows a weak correlation. The regression values for $\mathrm{SO} 2$ was $\mathrm{r} 2=0.14$. The south west wind direction favored high pollutant concentration in this study. The results for this study showed that the sites A-C were polluted with $\mathrm{SO} 2$.

\section{Relative Humidity}

The relative humidity was high as well as the pollutant level. The relative humidity ranged between 51 and $70 \%$ during wet season, 53 and $64 \%$ during dry season. High humidity reduces the amount of solar radiation reaching the earth's surface. This phenomena minimizes atmospheric temperature nearer to earth's surface, hence reducing up going 
currents affecting vertical mixing of air leading to trapping of air pollutants and eventually increase in pollutants. It exhibited a positive Pearson's correlation in relation to pollutant levels. The coefficient value for $\mathrm{SO} 2$ was $\mathrm{r} 2=0.59$.

\section{Temperature}

The temperature recorded in the study area ranged between $230 \mathrm{C}$ to $290 \mathrm{C}$ during both wet and dry season. During the dry season, the atmospheric temperature increased and the concentration of pollutants also increased due to failure of natural washout process.

\section{CONCLUSION}

During the dry season, the SO2, content for all the sites A-D had higher levels than the WHO value of $500 \mu \mathrm{g} / \mathrm{m} 3$. In the wet season, all the sites A-C also had higher levels except for site $\mathrm{D}(370 \mu \mathrm{g} / \mathrm{m} 3)$ which was lower than the WHO value. During the wet season, the level of pollution was much lower than during the dry season due to washout. During windy season, $(\geq 1.5 \mathrm{~m} / \mathrm{s})$ the level of pollution was less compared with calm periods that recorded higher values. When wind speed was high, pollutants was diluted by dispersion.

Relative humidity showed positive correlation with concentration of air pollutant. The higher the relative humidity the higher was the concentration of pollutant. However, temperature in this study had no correlation with pollutant level.

\section{ACKNOWLEDGEMENT}

The authors sincerely thank the Department of Chemistry, University of Nairobi who supported the project to its completion. Also to be appreciated is $\mathrm{Mr}$ Bernard Rop who assisted in the running of the Ultraviolet Spectrophotometer.

\section{REFERENCES}

1) Alias, M., Hamzah, Z. and Kenn, L. S. (2007). PM10 and Tota suspended particulates (TSP) measurements in various power stations. The Malaysian Journal of Analytical Sciences, 11 (1): 255-261.

2) Balmes, J. R., Fine, J. M. and Sheppard, D. (1987). Symptomatic broncho-constriction after short-term inhalation of sulfur dioxide. Am. Rev. Respir. Dis, 136: 1117.
3) GIS LAB. (2017). Athi River Town: University of Nairobi, Department of Geology (CBPS). Nairobi, Kenya.

4) Givoni, B. (1991). Impact of planted areas on urban environmental quality: A review atmospheric Environment, Part B. Urban Atmosphere, 25 (3): 289-299.

5) Government of Kenya. (2007). Ministry of Planning and National Development. Nairobi, Kenya: Kenya Vision 2030.

6) Kahenya, P. N. P. (1996). A review of studies on occupational diseases in Kenya. African Newsletter on Occupational Health and Safety Supplement, 2 (96): 46-49.

7) Lenchev, A., Ninov, J. and Grancharov, I. (2008). Atmospheric air pollution by the gas emissions of coal fired power plants II, ambient air pollution of the Stara Zagora region from the Maritsa East power complex. Journal of the University of Chemical Technology and Metallurgy, 43(3): 327334

8) Maina, D. M. (2004, June). Air pollution studies: issues, trends and challenges in Kenya. The role of nuclear analytical techniques in monitoring air pollution. Retrieved from IAEA: http://www.tc.iaea.org/tcweb/abouttc/strategy/The matic/pdf/presentations/pollution/AirPollutionStu diesinKenya.pdf.

9) Mogere, L. O. (2002). Determination of Concentration of Total Suspended Particulate Matter and some gaseous air pollutants in Athi river urban area, in kenya. MSc. Thesis. Nairobi, Kenya.: University of Nairobi.

10) Nemery, B., Hoet, P. H. M. and Nemmar, A. (2001). The Meuse Valley fog of 1930: an air pollution disaster. The Lancet, 357 (9257) : 704708

11) Park, J. E. and Park, K. (1985). Preventive and social medicine. Napier town, Jabalpur, India: Banarsida Bhanot.

12) Rao, S., Ku, J., Berman, S., Zhang, D. and Mao, H. (2003). Summer time characteristics of the Atmospheric boundary layer and relationships to Ozone levels over the Eastern United States. Pure Applied Geophysics, 160: 21-55. 